\title{
Kis méretü vesedaganatok patológiai és biológiai jellemzőinek elemzése a tumorméret alapján
}

\author{
Berczi Csaba dr. ${ }^{1}$ - Bacsó Zsolt dr. ${ }^{2}$ - Bidiga László dr. ${ }^{3}$ \\ Nagy Judit dr. ${ }^{4}$ - Flaskó Tibor dr. ${ }^{1}$ \\ ${ }^{1}$ Debreceni Egyetem, Általános Orvostudományi Kar, Urológiai Tanszék, Debrecen \\ ${ }^{2}$ Debreceni Egyetem, Általános Orvostudományi Kar, Biofizikai és Sejtbiológiai Intézet, Debrecen \\ ${ }^{3}$ Debreceni Egyetem, Általános Orvostudományi Kar, Pathológiai Intézet, Debrecen \\ ${ }^{4}$ Debreceni Egyetem, Általános Orvostudományi Kar, Radiológiai Klinika, Debrecen
}

\begin{abstract}
Bevezetés: A kis méretű vesedaganatok között lényegesen gyakoribbak a benignus elváltozások, és a kis malignus tumorok biológiai tulajdonságai is kedvezőbbek, mint a nagyobb daganatokéi.

Célkitüzés: Szerzők a kis méretű vesetumorok tulajdonságait vizsgáltuk különböző alcsoportokban.

Módszer: 2000. január l. és 2015. január 1. között 1272 beteg esetén végeztünk mútétet vesedaganat miatt. Közülük 496 betegnek volt kis méretû vesetumora. A betegek átlagéletkora $59 \pm 12$ év volt. A betegeket a tumorméret alapján három csoportba osztottuk. Az 1 . csoportban a daganat mérete $\leq 4 \mathrm{~cm}$, a 2 . csoportban $\leq 3 \mathrm{~cm}$ és a 3 . csoportban $\leq 2 \mathrm{~cm}$ volt.

Eredmények: Az eltávolított daganat nagysága átlagosan $29 \pm 8$ mm volt. A szövettan 418 esetben (84\%) malignus, míg 78 alkalommal (16\%) benignus elváltozást mutatott. A $2 \mathrm{~cm}$-nél kisebb daganatoknál malignitás csak az esetek $73,2 \%$-ában fordult elő. A malignus és a benignus tumorok méretében szignifikáns eltérés volt $(\mathrm{p}=0,008)$. Rosszul differenciált daganat - grade 3. és 4 . - az esetek 10,8\%-ában, 14,4\%-ában, illetve 20,7\%-ában volt jelen, amikor a tumorméret kisebb mint $2 \mathrm{~cm}, 2,1-3 \mathrm{~cm}$, illetve $3,1-4,0 \mathrm{~cm}$ volt. A vesecarcinomáknál az átlagosan 10 éves utánkövetési idő alatt progresszió az esetek 5,5\%-ában fordult elő.

Következtetés: A kis méretű vesetumor az összes vesedaganat 39\%-át tette ki. Ezek nagy része malignus volt, és benignus elváltozás az esetek 16\%-ában fordult elő. A malignitás előfordulása a $2 \mathrm{~cm}$-nél kisebb tumoroknál volt a legalacsonyabb. A tumorméret szoros összefüggést mutatott a malignitás gyakoriságával és a daganat differenciáltságával. A kedvező patológiai és biológiai eredmények alapján a $2 \mathrm{~cm}$ alatti daganatoknál felmerül annak lehetősége, hogy esetükben az aktív követés vagy minimálisan invazív kezelés alkalmazása kerüljön előtérbe.
\end{abstract}

Orv Hetil. 2021; 162(42): 1693-1697.

Kulcsszavak: benignus tumor, grade, kis méretű vesedaganat, malignitás, tumorméret

\section{Analysis of pathological and biological features of small renal masses based on the tumor size}

Introduction: The incidence of benign lesions is more common in small renal masses (SRMs) and biological behavior of small malignancies is better compared to larger ones.

Objective: The authors measured the characteristics of SRMs in different subgroups.

Method: From January 1, 2000 to January 1, 2015, 1272 patients underwent surgery for renal tumors. In 496 of the 1272 cases, the patients had SRMs. The mean age of the patients was $59 \pm 12$ years. Based on the sizes, the SRMs were divided into three groups. The sizes of the renal tumors were $\leq 4 \mathrm{~cm}$ in Group $1, \leq 3 \mathrm{~cm}$ in Group 2 and $\leq 2 \mathrm{~cm}$ in Group 3.

Results: The mean diameter of the removed SRMs was $29 \pm 8 \mathrm{~mm}$. Histology confirmed renal cell carcinoma in 418 cases $(84 \%)$, while benign tumor was present in 78 patients (16\%). However, with the tumor size $\leq 2 \mathrm{~cm}$, malignancy was detected in $73.2 \%$ of the cases. There was a significant difference in the sizes of the malignant and the benign masses $(\mathrm{p}=0.008)$. Grade 3 or 4 tumors were present in $10.8 \%, 14.4 \%$ and $20.7 \%$ when the tumor size was $\leq 2 \mathrm{~cm}$, 2.1 to $3 \mathrm{~cm}$, and 3.1 to $4 \mathrm{~cm}$ in diameter, respectively. During the mean 10-year follow-up period, tumor progression was detected only in $5.5 \%$ of malignancies. 
Conclusion: In 39\% of all cases, the patients had SRMs. The majority of SRMs were malignant, and benign lesion occurred only in $16 \%$ of the cases. The incidence of malignant tumors was the lowest when the size of SRMs was $\leq 2$ $\mathrm{cm}$. The size of the tumor was highly associated with probability of malignancy and tumor grading. Based on the favorable pathological and biological results in tumors below $2 \mathrm{~cm}$, active surveillance or minimally invasive treatment could be the preferred management.

Keywords: benign tumor, grade, malignancy, small renal masses, tumor size

Berczi Cs, Bacsó Zs, Bidiga L, Nagy J, Flaskó T. [Analysis of pathological and biological features of small renal masses based on the tumor size]. Orv Hetil. 2021; 162(42): 1693-1697.

(Beérkezett: 2021. március 7.; elfogadva: 2021. március 24.)

\section{Rövidítések}

$\mathrm{CT}=($ computed tomography) komputertomográfia; DE RKEB/IKEB = Debreceni Egyetem, Klinikai Központ, Regionális és Intézményi Kutatásetikai Bizottság; MRI = (magnetic resonance imaging) mágnesesrezonancia-képalkotás; SEER = Surveillance, Epidemiology and End Results; SRM = (small renal mass) kis méretú vesedaganat; TNM = tumor, node, metastasis; UICC $=($ Union for International Cancer Control $)$ Nemzetközi Rákellenes Szövetség

A kis méretű vesedaganatok (small renal masses, SRM-ek) előfordulási gyakorisága az utóbbi évtizedekben jelentősen nőtt, ami elsősorban a különböző képalkotó eljárások (ultrahang, CT, MRI) mind szélesebb alkalmazásának következménye [1-5].

Jelenleg a vesedaganatok 50-66\%-a SRM-ként kerül felismerésre, anélkül hogy bármilyen tünetet okozna. Az SRM definíciója azt jelenti, hogy a vesében levő szolid tumor nagysága nem nagyobb $4 \mathrm{~cm}$-nél [6]. Az SRM nagyon sokszor időskorban vagy olyanokban kerül felismerésre a rutin képalkotó vizsgálat során, akiknek más társult betegségük van $[5,7,8]$.

Jelenleg nagyjából az SRM-ek 70-90\%-a rosszindulatú daganat, míg a többi jóindulatú elváltozás.

Amikor a betegben SRM-et diagnosztizálnak, alapvetően három lényeges tényezőt kell figyelembe venni a terápia megválasztása során: a beteg morbiditását, a tumorkontroll biztosítását és a vesefunkció megőrzését [9].

Napjainkban az SRM kezelése során alkalmazhatunk sebészi beavatkozást (tumorreszekció vagy radikális nephrectomia), minimálisan invazív eljárásokat (rádiófrekvenciás ablatio vagy cryoablatio) vagy aktív követést. Jelenleg SRM esetén az „arany standard” terápia a tumorreszekció. Az ablativ kezelések elsősorban alternatív terápiaként végezhetők a beteg egyéb súlyos társult betegségei esetén. Az aktív követés pedig fóleg azokban az esetekben jön szóba, amikor a beteg nem egyezik bele a mútétbe, vagy társult betegségei miatt az nem kivitelezhető, de az idôsebb korosztályban (75 év feletti) is jól alkalmazható [10-17].
Az SRM-ek esetében a vizsgálatok nagy része azt mutatta, hogy ezen daganatok biológiai viselkedése lényegesen kedvezőbb, mint a nagyobb méretú tumoroké. Kevés olyan közlemény van azonban, mely a kis méretú daganatok tulajdonságait tanulmányozta még további alcsoportokban. Jelen tanulmányunkban az SRM-ek incidenciáját és tulajdonságait vizsgáltuk további - méret szerint felállított - alcsoportokban. A DE RKEB/IKEB engedély száma: 4831-2017.

\section{Betegek és módszerek}

2000. január 1. és 2015. január 1. között 1272 betegben végeztünk mútétet vesetumor miatt intézetünkben. Közülük 496 esetben SRM (méret $\leq 4 \mathrm{~cm}$ ) miatt történt az operáció. Az SRM-es betegek átlagéletkora $59 \pm 12$ év volt. Közöttük 222 nő és 274 férfi volt.

Az esetek nagy részében a tumorok incidentálisan kerültek felismerésre a rutinszerúen végzett ultrahangvizsgálat során. Az ultrahangot követően valamennyi betegnél CT- vagy MR-vizsgálat is történt. A képalkotó eljárások valamennyi esetben Tl-es stádumú daganatot mutattak. A preoperatív CT- vagy MR-vizsgálat 6 betegben nyirokcsomó-metastasist és 5 betegben távoli áttétet is kimutatott.

SRM esetében a mûtét során tumorreszekciót vagy radikális nephrectomiát végeztünk a daganat elhelyezkedésétől függően. A daganat stádiumát az UICC 2016. évi TNM-rendszere szerint határoztuk meg. A tumor differenciáltságának megadása a Fuhrman szerinti klasszifikáció szerint történt.

A betegek utánkövetése során a mútét után 6 hónappal ultrahang- és évente CT-vizsgálat történt.

$\mathrm{Az}$ átlagadatok mellett \pm standard deviációt adtuk meg. A statisztikai analízist Student-féle t-próbával végeztük. A 0,05-nél kisebb p-értékeket tekintettük szignifikánsnak. A korrelációs statisztikai vizsgálatok az online Wessa.net (Wessel P. [2016] Free Software Statistics, Office for Research, Development and Education, version 1.1.23-r7; http://www.wessa.net/) alkalmazásával történtek. 


\section{Eredmények}

A vizsgált időszakban 496 beteget operáltunk SRM miatt. Az eltávolított tumorok átlagos nagysága $29 \pm 8 \mathrm{~mm}$ volt. A szövettani vizsgálat 418 esetben vesesejtes carcinomát $(84 \%)$, míg 78 alkalommal (16\%) benignus elváltozást mutatott.

\section{Malignus kis méretü pesedaganatok (n: 418)}

A daganatok átlagos átméróje $30 \pm 7 \mathrm{~mm}$ volt. A betegek átlagéletkora $59 \pm 12$ év volt, és közöttük 178 nő (42\%) és 240 férfi ( $52 \%)$ volt.

A szövettani vizsgálat 4 esetben igazolt nyirokcsomómetastasisokat, és távoli áttét jelenléte 5 betegben volt ismert a diagnózis felállításakor. A szövettan az esetek $83 \%$-ában világos sejtes vesecarcinomát mutatott. A szövettani differenciáltság 116 alkalommal (28\%) grade 1., 230 esetben $(55 \%)$ grade 2., 67 tumornál (16\%) grade 3., míg 4 betegben (1\%) grade 4 . volt (1. táblázat). Így SRM esetében rosszul differenciált daganat az esetek 17\%-ában volt jelen.

Az átlagos utánkövetési idő 10,1 \pm 3,6 év volt. Az utánkövetési idő alatt tumorprogresszió az esetek 5,5\%ában fordult elő. Lokális recidíva 4 alkalommal, míg távoli metastasis 19 betegben alakult ki. A progresszióig eltelt idő átlagosan $38 \pm 3$ hónap volt. Ez a lokális recidívák esetében $21 \pm 13$ hónap, míg a távoli áttétek vonatkozásában $43 \pm 45$ hónap volt.

\section{Benignus kis méretü vesedaganatok (n: 78)}

A benignus elváltozások között oncocytoma az esetek 29,5\%-ában, angiomyolipoma a 28,2\%-ában, míg komplikált cysta a 23,1\%-ában fordult elö. A benignus tumorok átlagos nagysága $27 \pm 8 \mathrm{~mm}$ volt. A betegek átlagéletkora $56 \pm 12$ év volt, és közöttük 34 nő (43\%) és 44 férfi $(57 \%)$ volt.

1. táblázat |A malignus kis méretű vesetumorok szövettani jellemzői

\begin{tabular}{lccc}
\hline & $\leq 2 \mathrm{~cm}$ & $\leq 3 \mathrm{~cm}$ & $\leq 4 \mathrm{~cm}$ \\
\hline Szám (n) & 74 & 240 & 418 \\
Méret (mm) & $17 \pm 3$ & $24 \pm 5$ & $30 \pm 7$ \\
Világos sejtes RCC (n) & $58(78,4 \%)$ & $193(80,4 \%)$ & $347(83,0 \%)$ \\
Papillaris RCC (n) & $12(16,2 \%)$ & $28(11,7 \%)$ & $41(9,8 \%)$ \\
Chromophob RCC (n) & $4(5,4 \%)$ & $18(7,5 \%)$ & $27(6,4 \%)$ \\
Chromophil RCC (n) & $0(0 \%)$ & $1(0,4 \%)$ & $1(0,2 \%)$ \\
Ductalis RCC (n) & $0(0 \%)$ & $0(0 \%)$ & $3(0,6 \%)$ \\
Grade 1. (n) & $30(40,5 \%)$ & $73(30,4 \%)$ & $117(28 \%)$ \\
Grade 2. (n) & $36(48,7 \%)$ & $133(55,4 \%)$ & $230(55 \%)$ \\
Grade 3. (n) & $8(10,8 \%)$ & $33(13,8 \%)$ & $67(16 \%)$ \\
Grade 4. (n) & $0(0 \%)$ & $1(0,4 \%)$ & $4(1 \%)$ \\
\hline
\end{tabular}

RCC $=$ vesesejtes carcinoma
A betegek átlagéletkora malignus tumor esetén szignifikánsan magasabb volt, mint a benignus elváltozásoknál $(\mathrm{p}=0,036)$. A malignus daganatok szignifikánsan nagyobbak voltak, mint a benignus laesiók $(\mathrm{p}=0,008)$.

A tumorméret és a malignitás közötti összefüggést nemparametrikus korrelációanalízissel vizsgáltuk. A Spearman-féle ró $(\rho)$ és a Kendall-féle tau $(\tau)$ voltak kalkulálva, melyek mind elhanyagolható korrelációt mutattak $p=0,1084$ és $\tau=0,0933$ értékekkel. A $\rho$-és $\tau$-értékek szignifikánsak voltak a 0 -hoz $\mathrm{p}(\rho)=0,0158$ és $\mathrm{p}(\tau)=$ 0,016 értékekkel.

Az SRM-eket a méretük alapján három alcsoportba osztottuk. Az 1. csoportba azokat a betegeket soroltuk, akiknél a tumor nagysága $\leq 4 \mathrm{~cm}$ volt. A 2 . csoportban a tumorméret $\leq 3 \mathrm{~cm}$, míg a 3 . csoportban $\leq 2 \mathrm{~cm}$ volt. Így az 1. csoportba összesen 496, a 2. csoportba 288, míg a 3. csoportba 101 beteg tartozott. Az 1. csoportban rosszindulatú daganat 418 esetben $(84 \%)$, míg jóindulatú daganat 78 alkalommal (165) fordult elő. A 2. csoportban az elváltozások 83,3\%-a malignus és 16,7\%-a benignus volt. A 3. csoportban carcinoma a betegek $73,2 \%$-ában és benignus tumor a 26,8\%-ában volt jelen. A benignus elváltozások szignifikánsan gyakrabban fordultak elő a $2 \mathrm{~cm}$-nél kisebb méretü daganatok esetén $(\mathrm{p}=0,037)$.

A világos sejtes vesecarcinomák előfordulási gyakorisága $78,4 \%, 80,3 \%$, illetve $83,0 \%$ volt, amikor a tumorméret $\leq 2 \mathrm{~cm}, \leq 3 \mathrm{~cm}$, illetve $\leq 4 \mathrm{~cm}$ volt. Ugyanakkor a papillaris carcinomák incidenciája a következő volt: $16,2 \%$, $11,7 \%$, illetve $9,8 \%$ a $2 \mathrm{~cm}$-nél kisebb, a $3 \mathrm{~cm}$-nél kisebb, illetve a 4 cm-nél kisebb daganatnagyság esetén.

A daganat differenciáltsága szignifikánsan kedvezőbb volt a 3. csoportban az 1 . csoporthoz viszonyítva $(\mathrm{p}=$ 0,026). A 2. csoportban azonban a differenciáltság nem különbözött szignifikánsan sem az 1., sem a 3. csoporthoz viszonyítva $(p=0,21$ és $p=0,17)$. Az 1 . és a 2 . csoportban tumorprogresszió a betegek 5,5\%-ában és $1 \%$-ában alakult ki $(\mathrm{p}=0,99)$. A 3. csoportban, amikor a tumorméret $\leq 2 \mathrm{~cm}$ volt, daganatprogresszió nem jelentkezett. A tumorprogresszió szempontjából szignifikáns különbség volt az 1 . és a 3. csoport között $(\mathrm{p}=0,005)$, de nem volt szignifikáns különbség a 2. és a 3. csoport között $(\mathrm{p}=0,19)$.

\section{Megbeszélés}

Az SRM-ek incidenciája gyakorlatilag megháromszorozódott az utóbbi két évtizedben, s ez elsősorban az ultrahang és a CT egyre elterjedtebb használatának tudható be. Napjainkban az újonnan felfedezett vesedaganatok 50-70\%-a SRM [9].

Általában az SRM-ek 80\%-a malignus és 20\%-a benignus elváltozás [18]. Jelenleg elfogadott álláspont, hogy az elváltozás nagysága fontos tényező a daganat természetének meghatározása szempontjából, vagyis a nagyobb tumor valószínúleg malignus, és valószínúleg rosszabbul differenciált. 
Frank és mtsai úgy találták, hogy beningus elváltozás az esetek 30\%-ában volt kimutatható, amikor a daganat mérete kisebb volt, mint $2 \mathrm{~cm}$, és 21\%-ában, amikor a tumorméret 2 és $4 \mathrm{~cm}$ között volt. Nagy esetszámú vizsgálatukban (n: 2935) az 1 cm-nél kisebb daganatok 46,3\%-a, míg a legalább $7 \mathrm{~cm}$-es daganatok 6,7\%-a volt jóindulatú tumor [19]. Saját tanulmányunkban a $2 \mathrm{~cm}$ nél kisebb daganatok 26,8\%-a volt benignus, míg a 2-4 cm közöttieké 12,3\%-ban.

Az irodalmi adatok alapján, bár az SRM-ek többsége malignus, általában ezek alacsony stádiumúak és jól differenciáltak. Ennek eredményeként az SRM-ek rendszerint alacsony progressziós rátával rendelkeznek $[17,20]$. Néhány vizsgálatban tanulmányozták az SRM-ek növekedési rátáját az esetükben alkalmazott aktív követés során. A vizsgálatok eredményei azt mutatták, hogy ezen daganatok lassan növekednek $\mathrm{Az}$ átlagos növekedési ráta 0,13 és $0,26 \mathrm{~cm} /$ év között változott [21-23]. Emiatt az SRM-ek 5 éves daganatspecifikus túlélése kiválónak mondható, mert több mint 90\%.

Chawla és mtsai metaanalízisükben azt közölték, hogy a tumor mérete nem mutatott szignifikáns korrelációt sem a daganat növekedési sebességével, sem a metastasisok kialakulásával [21]. Agresszív daganat az SRM-ek között is elöfordulhat.

Nguyen és mtsai a SEER vesedaganatokra vonatkozó adatbázisának elemzése során azt tapasztalták, hogy a tumorméret jól korrelált a távoli metastasisok gyakoriságával. Azon betegekben, akiknél a daganat nem volt nagyobb, mint $4 \mathrm{~cm}$ (n: 8792), távoli áttét csak 5,2\%-ban volt jelen [24].

Saját anyagunkban a daganat diagnózisakor távoli metastasis az esetek 1\%-ában volt kimutatható, s a hosszú távú utánkövetés alatt a betegek 4,5\%-ában alakult ki új áttét.

Néhány közleményben arról számoltak be, hogy a nagyobb daganatoknál szignifikánsan gyakoribb a rosszul differenciált tumorok (grade 3. és 4.), valamint a papillaris carcinomák gyakorisága a kisebb daganatokhoz viszonyítva [25-27]. Remzi és mtsai vizsgálati eredményei azt mutatták, hogy a grade 3 . és grade 4 . differenciáltságú daganatok a $2 \mathrm{~cm}$-nél kisebb tumorokban 4,2\%-ban, a 2,1-3 cm közöttiekben 5\%-ban, míg a 3,1-4 cm közöttiekben $25,5 \%$-ban fordultak elő [18].

Vizsgálatunk során azt tapasztaltuk, hogy rosszul differenciált daganat (grade 3. és 4.) a kis méretû tumorok 17\%-ában volt jelen. A rosszul differenciált carcinomák az esetek 10,8\%-ában, 14,4\%-ában és 20,7\%-ában fordultak elö, amikor a daganat mérete $2 \mathrm{~cm}$ alatt volt, amikor 2,1-3 cm között volt, illetve amikor 3,1-4 cm között volt. Saját anyagunkban papillaris carcinoma az összes SRM 9,8\%-ában fordult elő, míg a 2 cm-nél kisebb daganatoknál az esetek 16,2\%-át alkotta.

\section{Következtetés}

Elmondhatjuk, hogy az SRM a daganatok 39\%-át tette ki. Ezen SRM-ek között benignus daganat az esetek 16\%-ában volt jelen. Mind a malignus tumorok, mind a rosszul differenciált carcinomák előfordulási gyakorisága a $2 \mathrm{~cm}$-nél kisebb elváltozások között volt a legkisebb. A $2 \mathrm{~cm}$ alatti daganatok esetén tumorprogressziót nem észleltünk. Így elmondhatjuk, hogy a tumor mérete szoros összefüggést mutatott a daganat malignitásával és differenciáltságával. A kedvező patológiai és biológiai jellemzőkre vonatkozó eredmények alapján a $2 \mathrm{~cm}$ alatti daganatoknál felmerül annak lehetősége, hogy esetükben a sebészi beavatkozás helyett az aktív követés vagy a minimálisan invazív kezelés alkalmazása kerüljön előtérbe. Ennek megerósítésére természetesen további randomizált klinikai vizsgálatok szükségesek.

Anyagi támogatás: A közlemény megírása, illetve az azzal kapcsolatos kutatómunka anyagi támogatásban nem részesült.

Szerzôi munkamegosztás: B. Cs.: A vizsgálat megtervezése, adatgyújtés, a cikk megírása. B. Zs.: Statisztikai vizsgálat. B. D. és N. J.: Adatgyújtés. F. T.: Szakmai felügyelet. A cikk végleges változatát valamennyi szerző elolvasta és jóváhagyta.

Érdekeltségek: A szerzőknek nincsenek érdekeltségeik.

\section{Irodalom}

[1] Ljungberg B, Albiges L, Abu-Ghanem Y, et al. European Association of Urology Guidelines on Renal Cell Carcinoma: the 2019 update. Eur Urol. 2019; 75: 799-810.

[2] Klatte T, Patard JJ, de Martino M, et al. Tumor size does not predict risk of metastatic disease or prognosis of small renal cell carcinomas. J Urol. 2008; 179: 1719-1726.

[3] Pantuck AJ, Zisman A, Belldegrun AS. The changing natural history of renal cell carcinoma. J Urol. 2001; 166: 1611-1623.

[4] Schiavina R, Borghesi M, Dababneh H, et al. Small renal mass managed with active surveillance: predictors of tumor growth rate after long-term follow-up. Clin Genitourin Cancer 2015; 13: e87-e92.

[5] Wagstaff PG, Zondervan PJ, De la Rosette JJ, et al. The role of imaging in the active surveillance of small renal masses. Curr Urol Rep. 2014; 15: 386.

[6] Gill IS, Aron M, Gervais DA, et al. Small renal mass. N Engl J Med. 2010; 362: 624-634.

[7] Phé V, Yates DR, Renard-Penna R, et al. Is there a contemporary role for percutaneous needle biopsy in the era of small renal masses? BJU Int. 2012; 109: 867-872.

[8] van Poppel H, Becke F, Cadeddu JA, et al. Treatment of localised renal cell carcinoma. Eur Urol. 2011; 60: 662-672.

[9] Zargar H, Samarasekera D, Khalifeh A, et al. Laparoscopic vs percutaneous cryoablation for the small renal mass: 15-year experience at a single center. Urology 2015; 85: 850-855. 
[10] Alam R, Patel HD, Osumah T, et al. Comparative effectiveness of management options for patients with small renal masses: a prospective cohort study. BJU Int. 2019; 123: 42-50.

[11] Deák PÁ, Korda DÁ, Doros A. Thermoablation therapy in the treatment of benign lesions. [Thermoablatiós lehetôségek a benignus térfoglaló képletek gyógyításában.] Orv Hetil. 2016; 157: 2040-2047. [Hungarian]

[12] Drangsholt S, Huang WC. Current trends in renal surgery and observation for small renal masses. Urol Clin North Am. 2017; 44: 169-178.

[13] Karam JA, Wood CG. Management of small renal mass: watch, cut, freeze, or fry? Eur Urol. 2012; 61: 905-906.

[14] Klatte T, Grubmüller B, Waldert M, et al. Laparoscopic cryoablation versus partial nephrectomy for the treatment of small renal masses: systematic review and cumulative analysis of observational studies. Eur Urol. 2011; 60: 435-443.

[15] Remzi M, Javadli E, Ozsoy M. Management of small renal masses: a review. World J Urol. 2010; 28: 275-281.

[16] Salagierski M, Wojciechowska A, Zając K, et al. The role of ablation and minimally invasive techniques in the management of small renal masses. Eur Urol Oncol. 2018; 1: 395-402.

[17] Volpe A, Cadeddu JA, Cestari A, et al. Contemporary management of small renal masses. Eur Urol. 2011; 60: 501-515.

[18] Remzi M, Ozsoy M, Klingler HC, et al. Are small renal tumors harmless? Analysis of histopathological features according to tumors $4 \mathrm{~cm}$ or less in diameter. J Urol. 2006; 176: 896-899.

[19] Frank I, Blute ML, Cheville JC, et al. Solid renal tumors: an analysis of pathological features related to tumor size. J Urol. 2003; 170: 2217-2220.
[20] Youn CS, Park JM, Lee JY, et al. Comparison of laparoscopic radiofrequency ablation and open partial nephrectomy in patients with a small renal mass. Korean J Urol. 2013; 54: 603608.

[21] Chawla SN, Crispen PL, Hanlon AL, et al. The natural history of observed enhancing renal masses: meta-analysis and review of the world literature. J Urol. 2006; 175: 425-431.

[22] Jewett MA, Mattar K, Basiuk J, et al. Active surveillance of small renal masses: progression patterns of early stage kidney cancer. Eur Urol. 2011; 60: 39-44.

[23] Mason RJ, Abdolell M, Trottier G, et al. Growth kinetics of renal masses: analysis of a prospective cohort of patients undergoing active surveillance. Eur Urol. 2011; 59: 863-867.

[24] Nguyen MM, Gill IS. Effect of renal cancer size on the prevalence of metastasis at diagnosis and mortality. J Urol. 2009; 181 : $1020-1027$.

[25] Ha SB, Kwak C. Current status of renal biopsy for small renal masses. Korean J Urol. 2014; 55: 568-573.

[26] Schlomer B, Figenshau RS, Yan Y, et al. Pathological features of renal neoplasms classified by size and symptomatology. J Urol. 2006; 176: 1317-1320.

[27] Steffens S, Junker K, Roos FC, et al. German Renal Tumor Network. Small renal cell carcinomas. How dangerous are they really? Results of a large multicenter study. Eur J Cancer 2014; 50: 739-745.

(Berczi Csaba dr., Debrecen, Nagyerdei krt. 98., 4032 e-mail: berczi@med.unideb.hu)

\title{
MEGHÍ Vó
}

\section{Az Észak-Közép-budai Centrum, Új Szent János Kórház és Szakrendelő Tudományos Bizottsága tisztelettel meghívja az érdeklődőket a következő tudományos ülésére.}

Időpont: 2021. október 28. (csütörtökön) 14.00 óra

Helyszín: Szent János Kórház Auditóriuma - 1125 Budapest, Diós árok 1-3.

\author{
Üléselnök: Prof. Dr. Hirschberg Andor és Dr. Schandl László
}

\section{Program:}

Schandl László dr., Lengyel Zoltán dr., Nyulasi Tibor dr., Szócska Gábor dr, Molnár Beatrix dr., Istráb Tünde dr., Trócsányi Márta dr., Kazinczy Rita dr.: A COVID-pandémiával kapcsolatos intézeti betegellátás tapasztalatai számokban és nem számokban

Gombos Katalin dr., Kerkay Györgyi dr.: A szemfelszín betegségei és összefüggései más általános betegségekkel. Lehetséges kezelési módok, új mütéti megoldások.

\section{Interaktív kerekasztal}

Minden érdeklődőt szeretettel várunk!

A cikk a Creative Commons Attribution 4.0 International License (https://creativecommons.org/licenses/by/4.0/) feltételei szerint publikált Open Access közlemény, melynek szellemében a cikk bármilyen médiumban szabadon felhasználható, megosztható és újraközölhetö, feltéve, hogy az eredeti szerző és a közlés helye, illetve a CC License linkje és az esetlegesen végrehajtott módositások feltüntetésre kerülnek. (SID_1) 